\title{
CONTEXTUAL FACTORS OF FAMILY REUNIFICATION AND SOCIAL ADAPTATION
}

\begin{abstract}
Purpose - to present contextual factors of destination country and discuss about their role and potential impact for family reunification and family migrants' social adaptation.

Design/methodology/approach - secondary data analysis and qualitative research.

Findings - Sociological analysis of ethnic minorities' and migrants' social adaptation suggests taking into account the relevance of social context of the receiving society. In order to explain the concept of social context, it is suggested to apply segmented assimilation theory. According to the theory social context of the receiving society consists of three items: migration and migrants' integration policies implemented by the host country's government; receiving society's attitudes and prejudices about immigrants; co- ethnic communities of immigrants and their resources to support newcomers. This paper discusses about the role and potential impact of the first item - migration and migrants' integration policy for family migrants' social adaptation. Migration policy is one of the most important contextual factors as it is the first one that migrants face and continually have to deal with their entire life in the destination country.

Empirical data of the research, which aim was to reveal patterns of social adaptation of persons reunified with their family members in Lithuania (family migrants), confirms that social context of the host country has an impact for migrants' social adaptation into receiving society. The analysis of national policies in the context of family reunification and secondary data analysis of the study MIPEX suggest that conditions for family reunification in Lithuania are 'halfway favourable', but the status of family migrants is extremely vulnerable. Migration policy and its measures applied for family reunification in Lithuania can be ascribed to the governmental response of 'passive acceptance' there is a possibility to reunify with the family in Lithuania, but the process to receive residence permit is very bureaucratic and long-lasting, and, consequently, limiting migrants' social adaptation.

Research limitations/implications - This study broadens the knowledge of the phenomenon of family reunification in Lithuania and suggests a theoretical insight to study social adaptation of family migrants taking into account the impact of contextual factors of the receiving society by applying the segmented assimilation theory.

Originality/Value - The study focus on the phenomenon of family reunification, which is methodologically and empirically, marginalized in the context of migration research both on national and international level. Besides, it suggests a theoretical insight to study family migrants' social adaptation taking into account the impact of contextual factors of the receiving society by applying segmented assimilation theory.
\end{abstract} policy.

Keywords: immigration; family reunification, social adaptation, contextual factors, migration

Research type: research paper

JEL classification:

J6 - Mobility, Unemployment, Vacancies, and Immigrant Workers

K37 - Immigration Law

${ }^{1} \mathrm{PhD}$., Lithuanian Social Research Centre, Institute for Ethnic Studies, Lithuania, giedre@ces.lt 


\section{Introduction}

Family-related migration remains the most popular ground of arrival of non-European Union (non-EU) nationals to Europe for several decades. It is also one of the most popular grounds of arrival of non-EU citizens to Lithuania. Furthermore, statistical data reveals that persons, who arrive to the country to reunify with their family members (hereinafter family migrants), extend residence permits more often than other groups of migrants. This shows that family migrants are more likely to associate their life with Lithuania and their stay in the country is not temporary.

Social studies emphasize the relevance of family reunification to improve cultural stability and social life of a reuniting family and separate its family members in the receiving society (Huddleston, Tjaden, 2012). However, it is also important to take into account that social adaptation into receiving society depends not only on the private, but also on the external circumstances.

Sociological studies of ethnic minorities' and migrants' social adaptation suggest taking into account the relevance of social context of the receiving society as it can influence the result of social adaptation which is interpreted as "the outcome of pursuit of status and the social environment" (Kasatkina, Leončikas, 2003:219).

In order to explain the concept of social context, the author of this article suggests applying segmented assimilation theory. According to this theory social context of the receiving society consists of three items: migration and migrants' integration policies implemented by the government of the host country; receiving society's attitudes and prejudices about immigrants; co- ethnic communities of migrants and their resources to support newcomers.

The aim of the article is to present contextual factors of destination country and discuss about their role and potential impact for family reunification and family migrants' social adaptation. Contextual factor of migration and migrants' integration policy is chosen for broader discussion in the article. This is one of the most important contextual factors that migrants face at first and continually have to deal with their entire life in the destination country.

The discussion is supplemented by the examples from the qualitative study "Immigration for family reunification to Lithuania: the role of gender and ethnicity in the process of social adaptation" carried out in 2013-2016. The aim of the study was to investigate patterns of social adaptation of migrants on the ground of family reunification by assessing the impact and the links of social context, gender and ethnicity. 32 non-EU nationals, who arrived to the country for family reunification with their spouses, and 7 practitioners and stakeholders, who work in the field of migration and migrants' integration (both governmental and non-governmental sectors), were interviewed for the study.

The first chapter of the article briefly introduces theoretical insights of social adaptation and theory of segmented assimilation mainly focusing on how it explains contextual factors of the destination country. Family reunification policy in Lithuania is presented in the second chapter. Here the requirements for family reunification in Lithuania are described and a comparative analysis with other EU Member States based on the results of international study Migrants Integration Policy Index (MIPEX) is provided. The third chapter is devoted to present if and how family reunification policies might cause social adaptation of family migrants into receiving society. Provided information is supplemented by the personal experiences of family migrants and opinion of experts working in the field of migrants' integration who participated in the empirical research. This chapter reviews the main obstacles and challenges that family migrants face in Lithuania. The article is finished with the 
conclusions, which also include some recommendations for the migration and migrants' integration policy-makers.

\section{Theoretical background}

\section{Contextual factors of migrants' social adaptation}

Family plays an import role for migrants' adaptation in the destination country. Social studies (Huddleston and Tjaden, 2012; Huijnk et al., 2012; Pascouau and Labayle, 2011) reveal that migration to family members settled in a foreign country ensures help and support, as well as informal social networks which can provide valuable and important information facilitating family migrants adaptation into receiving society. Family reunification helps to improve cultural stability and social life, meanwhile the relationship among family members can help to maintain ethnic identity and a sense of belonging to one or another ethnic group. Huddleston and Tjaden noted that "family reunion is not just a channel for the immigration of families, but also the starting point for integration" (2012:54)

Studies of social adaptation of ethnic minorities and migrants are widely spread and there are different theoretical and methodical approaches to study the subject, which have been changing through time. In early studies of the phenomenon dominated an unidimensional approach, which explained adaptation as a process, when migrants give up their ethnic identity and adopt norms of behaviour and practices of the receiving society (R. Park, E.W. Burges (1921); Gordon, 1964). Later this approach was changed by the bi-dimensional approach, according to which adaptation is the long-term result of acculturation. This approach is represented by cross cultural psychologist J.W.Berry, who referred adaptation to "changes that take place in individuals or groups in response to environmental demands" (1997:14). The scholar identified four kinds of acculturation strategies - integration, separation, assimilation and marginalization. Berry's scheme of acculturation strategies was based on individual attitudes as the scholar assumed that they are consciously chosen (Kasatkina and Leončikas, 2003).

Lithuanian scholars Kasatkina and Leončikas (2003) noticed that if it is legitimated for psychological research to consider acculturation variants as consciously chosen strategy, in sociological research it should be paid attention to the fact that not everything depends on the individual and "type of adaptation is therefore more than strategy of individual behaviour" (2003:219). These scholars suggested to emphasize the social context which can influence the result, or, in other words, type of adaptation which is interpreted as "the complex outcome of the pursuit of status and the social environment" (2003:219). Kasatkina and Leončikas (2003) proposed the adjusted scheme of adaptation types, which concentrates along two lines satisfaction with the achieved status and maintenance of ethnic identity.

The author of this paper suggests operationalizing social context by applying segmented assimilation theory. The representatives of this theoretical approach claimed that migrants confront a number of contextual factors of the receiving society, which shape the way they are incorporated into it (Portes et al., 2001). In accordance to segmented assimilation theory there are three types of contextual factors that might have an impact for newly arrived migrants' incorporation into receiving society: 1) host government's policies of migration and migrants integration; 2) receiving society's attitudes and prejudices about migrants; 3) migrants' co-ethnic communities and their resources to support newly arrived migrants (Portes, Rivas, 2011; Portes et al., 2001).

According to the segmented assimilation theory, the first contextual factor that newcomers confront is policies of the receiving government. Portes (et al., 2001) distinguish 
three options of possible governmental responses that might be 1) exclusion; 2) passive acceptance; or 3) active encouragement.

Enforced policies of 'exclusion' prevent immigration or "forces immigrants into a wholy underground and disadvantaged existence" (Portes et al., 2001:46).

Governmental response of 'passive acceptance' means policy measures, when migrants are granted legal access to the destination country, but the state authorities do not take any additional measures to facilitate their adaptation into receiving society (Portes et al., 2001). Portes (et al., 2001:47) notice that such neutral position of the host government "places newcomers under the protection of the law, but does not grant them any special concessions to compensate for their unfamiliarity with their new environment."

The third option of possible governmental response is 'active encouragement', which is explained as policy measures that aim to attract a certain group of migrants to the destination country and to facilitate their establishment and living conditions in the receiving society. This kind of support is crucial, because it provides access to resources that is not available to other groups of migrants (Portes et al., 2001).

The second contextual factor is the reception of the receiving society of newcomers. Sociological studies confirm that reception of migrants depends on their familiarity with the mainstream of the receiving society - "the more similar new minorities are in terms of physical appearance, class background, language and religion (...) the more favourable their reception and the more rapid integration" (Portes et al., 2001:47).

Migrants' co-ethnic communities and their resources represent the third contextual factor. In some cases such communities do not exist in the destination country, but mostly migrants go the places, where some social networks already exist. These communities are especially important at the beginning of the life in a new country. They provide assistance for finding work and/ or a plce of residence, provide important information regarding to foreign culture, places of shops and schools for the children. They also play important role for spreading social network in the host society. Portes (et al., 2001) emphasize that assistance of co-ethnic communities differs depending on the information and the resources they own.

Portes and his colleagues state that governmental, societal and communal levels of reception "compromise the mode of incorporation of a particular immigrant group" (2001:48). Scholars emphasized that immigrants' ambitious and motivation to incorporate into receiving society are not so important as their future depends on the contextual factors they face in the receiving society - "their future prospects will be dim if governmental officials persecute them, natives consistently discriminate against them and their own community has only minimum resources to offer" (2001:49).

The first contextual factor - migration and migrants' integration policy - is chosen for the broader discussion in the article. There are few reasons explaining this choice that are mainly related to the fact that migration policy is one of the most important contextual factors - it is the first one that migrants face and continually have to deal with their entire life in the destination country. The next two chapters will present family reunification policy implemented in Lithuania both overviewing it from the legislative side, and from the personal experiences of family migrants settled in the country.

\section{Family reunification in Lithuania: migration policy and its measures}

Family reunification remains the main immigration channel for people to move to Europe for the past few decades (Huddleston, Tjaden, 2012; Castles, Miller, 2009). The latest statistical data shows that 779 thousand residence permits in the EU Member States were issued for the family related reasons in 2016. The relative share of these residence permits 
was $23 \%$ in the total number of first residence permits issued in the EU-28 (Eurostat, 2017). According to the Eurostat data (2017), in 2016 family related reasons were the most common reasons for issuing residence permits in 11 EU Member States.

Family reunification is one of the most popular grounds for the issuance residence permits for non-EU nationals in Lithuania as well. Since 2005 to 2015 the number of residence permits issued on the ground of family reunification was stable increasing. The situation changed in 2016, when residence permits for foreigners who intended to take up employment in the country made up the greatest share of all residence permits issued/ replaced during that period. For the past two years, family reunification remains in the second place by the number of issued/ replaced residence permits for non-EU nationals in the country. In 2017, 4546 residence permits were issued/ replaced in case of family reunification and the relative share of these residence permits was around $24 \%$ in the total number of all issued/ replaced residents' permits in the country during that year. Besides, analysis of the statistical data reveals that family migrants belong to the group of foreigners who are more likely to associate their life with Lithuania. The assumption that their residence in the country is not temporary is based on the numbers of the replaced residence permits on the grounds of family reunification, which constituted $69 \%$ of the total number of all issued/ replaced residents' permits on this case in 2017.

Law on Legal Status of Aliens (No IX-2206, 2004) (hereinafter the Law) is the main legal act, which regulates migration processes in Lithuania. This document foresees eight possible cases of family reunification in the country (e.g. foreigner's parents or one of them, who are citizens of the Republic of Lithuania, reside in the country; foreigner's child, who is a citizen of the Republic of Lithuania, resides in the country, etc.) (see art. 43(1)). Statistical data reveals that the most popular of them is arrival to the spouse or registered partner, who is a citizen of the Republic of Lithuania or a foreigner in possession of a residence permit in the country (art.43(1)(5)). This case of family reunification constituted $63 \%$ of the total number of residents permits issued on the ground of family reunification in 2017.

The high number of persons who arrive to Lithuania for family reunification and the perspectives of these persons to stay in the country permanently require ensuring welcoming conditions for their entrance and facilitating their social adaptation into receiving society.

Analysis of migration and migrants' integration policy in Lithuania reveals that policy measures in the context of family reunification could be referred, speaking in the terms of the segmented assimilation theory, to the governmental responses of 'active encouragement' and 'passive acceptance'.

'Active encouragement' policy could be assigned to highly qualified workers and their family members. First of all, persons, who intend to take up highly qualified employment in the country, receives the decision on the residence permit sooner comparing with other groups of migrants - not later than within two months from the lodging the application (in regular case not later than within four months) and the permit is issued for the longer period - for three years (in regular case for two years). In the context of family reunification highly qualified workers can reunify with the family immediately - the most criticised requirement for family reunification, obligation to be resided in the country for the last two years, is not applied for this group of migrants. However, highly qualified workers and their family members constitute only a minor part of migrants in Lithuania $(1,4 \%$ in 2017). For the majority of newcomers in Lithuania governmental response of 'passive acceptance' could be applied - migrants have legal access to the country, but additional measures to facilitate their adaptation are not taken by the government.

Regarding to the issuance of the residence permit on the ground of family reunification, the following requirements are foreseen in the art. 26 of the Law: (1) to have a valid 
document evidencing health insurance coverage; (2) to have sufficient means of subsistence and/ or receive regular income which is sufficient for his/ her stay in the Republic of Lithuania; (3) to possess by the right of ownership the suitable residential premises in Lithuania (the residential area per each adult person who has declared the place of residence at it would not be less than seven square metres); (4) age restriction (both foreigners who have contracted the marriage or registered partnership agreement must be no younger than 21 years of age); (5) the foreigner, whose family members enter by virtue of family reunification, must have resided in the country for the last two years, hold a temporary residence permit valid for at least one year and have reasonable prospects of obtaining the right to permanently reside in Lithuania.

A temporary residence permit on the ground of family reunification is issued for the same period as the period for which temporary residence permit has been issued to the foreigner to whom it is coming for the reunion. Foreigner, who by virtue of family reunification joins the foreigner in possession of a permanent residence permit or joins a citizen of the Republic of Lithuania is issued a temporary residence permit for a period of one year or renewed for a period of two years (Art. 43(5)).

International study of Migrant Integration Policy Index (hereinafter MIPEX), a tool, which measures policies to integrate migrants in all EU Member States and in some OECD countries, reveals that Lithuania has far to go to develop strong and comprehensive integration policies. Lithuanian's current policies rank 34th out of 38, slightly below average for Central Europe. According to the results of the study MIPEX 2015 integration policies, implemented in Lithuania, are called as slightly unfavourable for integration of current and future immigrants (Huddleston et al., 2015).

MIPEX 2015 ranks family reunification policies $22^{\text {nd }}$ out of 38 indicating them as 'halfway favourable' for integration of current and future immigrants. In the report of the study it is noticed that the state authorities create as many opportunities and obstacles for non-EU migrants to reunite in Lithuania as is average in Europe (Huddleston et al., 2015). The most criticized requirement for family reunification is the delay to reunify with the family (sponsors who meet the requirements are forced to wait to apply for two years). Besides, family reunion "procedures are also relatively discretionary, a typical problem across Central Europe" (Huddleston et al., 2015). Furthermore, the results of MIPEX 2015 reveal that status of family migrants (in terms of maximum duration of procedure; duration of validity of permit; grounds of rejection, withdrawal, refusal; personal circumstances considered issuing residence permit; legal protection) is the one of the most vulnerable comparing with other countries of the study.

Comparing family reunification requirements in Lithuania with other EU Member States, it could be mentioned that Lithuania applies quite inclusive definition of family members who are entitled to join their sponsor (it includes spouses and persons with whom they have a registered partnership; minor/ adopted children; direct relatives in the ascending line (art. 2(26)). For instance, full entitlement for partners are applied in 11 EU Member States (SL, UK, DK, ES, FI, SE, IE, BE, PT, LU, NL), for parents and grandparents in 8 EU Member States (LU, SE, SI, HU, RO, LT, PT) and for adult children only in 5 EU Member States (SE, CZ, PT, SL, ES) (MIPEX 2015). However, Lithuania is among 4 EU Member States (AT, UK, DK, LT) which require higher age limit comparing with other countries; among 7 EU countries (AT, BE, FR, EL, LT, LU, UK) that have restrictive income requirements and among 8 EU countries (AT, EL, FR, IT, HU, MT, UK, LT) that have strict housing requirements (MIPEX 2015).

The next chapter will present how migration policy works in practice. Provided information will be based on the personal family migrants', who were interviewed for the social study, experiences. 


\section{Research methodology}

In order to investigate the patterns of social adaptation of family migrants by assessing the impact and the links of social context, gender and ethnicity, a qualitative study was implemented in 2013-2016.

Totally 32 family migrants (persons who arrived to the country for family reunification with their spouses or partners) from non EU countries and 7 practitioners and stakeholders in the field of migration and migrants' integration were interviewed for the study. Semistructured interviews were done in Vilnius, Kaunas and Klaipeda - the cities that attract the majority of migrants of the country. The anonymity and confidentiality of the informants were ensured and all participants of the study gave the permission to participate voluntary in the research.

\section{Research results and findings}

\section{Migration policy and its measures: the impact for family migrants' social adaptation process}

Experts, who participated in the study, critically evaluated the conditions of family reunification in Lithuania claiming that the legal procedure is complicated (NVO-1, Vilnius) and getting more tightened by introducing additional requirements and examination (VI-4, Vilnius).

Mostly experts expressed their critique for the requirement related to the obligation to show that person has sufficient means of subsistence and receives regular income which is sufficient for his/ her stay in the country and the mandatory period of residence in Lithuania for those who want to invite their family members.

The amount of sufficient means of subsistence for living in Lithuania for foreigners (except those who intend to study, to participate in traineeship programmes, to improve qualifications and foreigners who are under 18) is established by the Minister of Social Security and Labour and is 400 EUR per month (from $1^{\text {st }}$ of January 2018). From the first sight it seems that amount is not so big as it match the amount of one minimum monthly wage in the country. However, the national laws foresee that foreigner has to show that (s)he has the required amount not for one month, but for the entire period of the issued residence permit. In accordance to the provisions of the Law on Legal Status of Aliens (hereinafter the Law), residence permit on the ground of family reunification, when person reunify with his/ her spouse or registered partner in Lithuania, is issued for one year and is extended for two years. This means that at the beginning family migrant must show that (s)he has 4800 EUR in his/ her account and after one year that there are 9600 EUR in his/ her account. Interviewed experts emphasised that it is a big amount of money in Lithuania (...) not every person, especially living in district areas or countryside (...) for them it might be like additional burden (VI-4, Vilnius).

Majority of interviewed family migrants also mentioned that this requirement was hardly achievable for them. The research reveals that families, who face this problem, try to find various ways to solve it. Some of them borrow money from friends or relatives, bring the required amount to the bank and when all the formalities to receive a residence permit are finished, they take money back from the bank to return to the ones they borrow the money from. This practice shows how strict and not flexible rules can induce negative consequences and encourage various illegal measures to stay in the country. 
However, the representative of Migration department (VI-4, Vilnius) stated that officers of the institution look to this requirement quite flexible. In some cases the officers ask to provide evidences that person has a required money in his/ her account for one year and later person has to make a commitment that (s)he will show the required amount as soon as (s)he has it. The expert from Migration department thinks that it should be some exceptions for family migrants regarding to this requirement. At this moment all migrants (labour migrants, migrants who intend to study in the country, etc.) have to have the same amount of sufficient means of subsistence for living in Lithuania.

Interviewed experts also criticized the requirement which delay family reunion in Lithuania. As it was mentioned before, according to the Law foreigners who want to reunify with their family in the country must be resided in the country for the last two years. Some of the experts claimed that this might become a reason why foreigners do not choose Lithuania as the country of destination (NVO-2, Vilnius), while others think that such requirement could be a pretext for foreigners to search irregular ways to entry the country (VI-4, Vilnius).

However, the representative of the institution responsible for migration policy implementation in Lithuania (VI-4) claims that this requirement is important to control the flows of migrants to the country. Such opinion expressed by the representative of Migration department reflects the current migration policy of the country, when by amending the laws it is being shaped increasingly difficult conditions for foreigners to enter and to settle in the country.

The data of empirical study reveals that persons, who decide to reunify with the family in Lithuania, face many obstacles and challenges that are caused by the migration policy of the country. Most of them mentioned the problems related to the issuance of the residence permit - long lasting and very bureaucratic procedure cause that persons are frequently forced to think if they will be able to stay in the country with the family, but not how to incorporate into the receiving society (to study Lithuanian language, spread social networks in the local community, etc.).

The Law foresees that the application for issue or renewal of a residence permit must be examined "not later than within four months from the lodging an application with the relevant institution" (Art. 33(1)(1)). According to the Law, foreigners, who do not have a residence permit, are able to stay in the country for a maximum of 90 days in a 180-day period (Art. 11). The experiences of the participants of the study show that the procedure to issue residence permit usually takes longer than persons have a right to stay legally in the country. A representative of one NGO briefly described the issue $<. . .>$ you lodge an application for the residence permit, then you have to wait for a half of the year (...), but your visa is valid only for three months. You have to leave the country for three months and then return to Lithuania, to receive visa and, finally, receive a residence permit. (NVO-3, Klaipèda)

The fact that the process usually takes more time is also proved by the personal stories of the participants of the study. Some of them (M-28, Brazil; V-13, India, V-16, Egypt) even told that they had to wait for the decision to issue residence permit until the last day of the validity of the visa.

$<. .>$ I was waiting 80 days, but the decision was not made. (...) If I stay longer than 90 days here, it means that I am here illegally (...). So I bought a ticket to Egypt after 80 days waiting for the decision and, it is funny, that I received an answer regarding to the decision to issue residence permit for me at 89 day of my stay here. (V-16, Egypt)

Interviewed family migrants called the procedure of issuance residence permit a game and $a$ lottery that everyone who moves to Lithuania is forced to play. 
$<. .>$ It was kind of game, I would say. But I think they [personnel of Migration department] are doing this with everyone because of the fake marriages. To see if somebody give up or still trying to go to the end. (V-14, Iran)

There is a possibility to apply for the application for the issuance of the temporary residence permit in the urgent order. In this case the procedure of examination the application and processing of temporary residence permit is shortened by half - the application is examined for two months and the residence permit is processed during five days. However, this service is double expensive comparing with the one done in the general order. Although some of the participants of the study mentioned that they used the opportunity to receive residence permit in the urgent order, the interviewed experts noticed that despite the fact that the fee is not so big, but for some families it is additional burden and not everybody can allow paying extra money.

The results of the study reveal that foreigners do face the problem not only during the waiting period for the residence permit, but also later, when they have to extend them. The Law foresees that persons, who have temporary residence permit on the ground of family reunification, have to extend their residence permit after one year and later after two years. Before the amendments of the Law in June 2014, family migrants had to extend their residence permit each year. New regulations are more adapted to migrants who live here with their families. Experiences of family migrants, who faced the regulations to extend residence permit each year, reveal that such conditions cause feelings of insecurity and transience.

Family migrants also face the problems changing temporary residence permits to the permanent ones. According to the article 53(8) of the Law, a foreigner may be issued a temporary residence permit, if (s)he "has resided in the Republic of Lithuania uninterruptedly for the last five years holding a temporary residence permit". The experiences of interviewed family migrants show that even small breach of the law can cause possibility that the temporary residence permit will not be changed to the permanent one and the circumstances that person lives in Lithuania with his/ her family, has children, works and has his/ her own accommodation do not play any role.

$<. .>$ we missed the deadline by two weeks and so I was never able to get five years. (...) it was accidently two weeks gap in between of those years and then they made me counting again. (...) Anybody can see that I live for eight years right now with my family (...) it is a little crazy (V8, USA)

Most of the interviewed family migrants were very disappointed about the requirements applied for newcomers and for foreigners who live in the country with their families for some time. As participant of the study from USA (V-1) noticed they [Migration department] don't have the system for people who have actually families here to stay without having to ask permission to stay ( $\mathrm{V}-1$, USA). Both experts and family migrants emphasised the importance to issue residence permits for family migrants for a longer period, as well as to make more flexible regulations concerning the extension of the residence permit.

The experiences of family migrants reveal several reasons that might cause the difficulties and challenges that family migrants face to during the procedures of issuance and extension of residence permits in the country. First of all, participants of the study mentioned a great bureaucratic apparatus and, consequently, long-lasting procedure of examining and processing residence permits. Most of the interviewees claimed that they had to approach to Migration department for several times in order to provide documents relevant for the residence permit. It is noticed that it might be related with the lack of information regarding to the all bureaucratic procedures. While experts mentioned that this problem is caused because of the fact that foreigners do not speak Lithuanian language, family migrants noticed that it is relevant to provide more detailed information in English and Russian on the website 
of Migration Department. In very truth, after reviewing information provided on the website, it is visible that provided information is not always accurate and more detailed information, especially regarding to the amended laws, is available only in Lithuanian.

$<\ldots>$ it is elementary lack of information (...) immigrants do not speak Lithuanian, do not know where to go and what to read, consequently, they don't know where to get information they need (NVO-3, Klaipèda)

Furthermore, issue of the lack of information is also related with the way how information is provided by the officers of Migration divisions. Participants of the study shared their experiences that in some cases they had to come back to the institution for several times just because different officers provided different information regarding to the document they had to provide.

The cases, when officers provide different information for family migrants could be connected with the relatively frequent amendments of the Law. It is important to note that with the amendments of the Law, the sub-statutory acts are also changing and that may cause the issue for the officers to provide the latest information for the applicants. One of the interviewed experts also noticed this problem and emphasized the relevance of clear and long-term migration policy strategy.

$<\ldots>$ we have to decide what we are trying to achieve with the regulation [of the migration policy] and that it would keep stable for at least one year (VI-3, Klaipeda)

The stories shared by the participants of the study reveal that migration policy and its measures create unfavourable conditions for family migrants to arrive and to stay permanently in Lithuania. From the beginning these families face great challenges to stay together in the country, thus they usually start to think about other destinations. The results of the study show that many of the interviewees do not think about their social adaptation into receiving society (e.g. learning language, search friends in the local community, etc.) until they are not sure about their status in the country as they are convinced that their and their families' life in Lithuania might be temporary. In some cases the feeling of insecurity is followed for a longer time and even after the residence permit is received. As it was mentioned before, even persons, who live in the country for some time, identified their feelings of insecurity and uncertainty about their future.

\section{Conclusions}

The aim of the article was to present contextual factors of destination country and discuss about their role and potential impact for family reunification and family migrants' social adaptation. This paper presented one of the contextual factors - migration and migrants' integration policy implemented in Lithuania - both from legislative level and from the side of personal experiences of family migrants who are settled in the country.

The migration policy in the context of family reunification applied in Lithuania can be attributed to governmental response of 'active encouragement' for highly skilled migrants and their family members and 'passive acceptance' for the majority of migrants and their family members. The main law that regulates migration process in Lithuania - Law on Legal Status of Aliens - foresees the set of requirements that persons, who want to reunify with the family, have to meet. The most criticized requirement by the international and interviewed national experts is the delay of family reunification - the sponsor (person whose family members want to join them in Lithuania) must stay in the country for two years and only after this period they can reunify with the family. Interviewed experts and family migrants also responded critically about the requirement to have the amount of sufficient means of subsistence for living in Lithuania for the period of validity of their residence permit. For 
some families, especially ones who live in smaller towns or rural places, to show that they have sufficient means of subsistence for two years is really difficult and in some cases persons are trying to search illegal ways meet this requirement.

The experiences of family migrants reveal that they face many obstacles and challenges caused by the migration policy of the country. Unwillingness to be open for migrants and not clear long-term migration policy strategy of the country predetermines bureaucratic and long-lasting procedures of issuance and extension of temporary and permanent residence permits. Migrants have to approach to Migration divisions for several times, different officers usually provide different information, lack of information on-line and, finally, long-lasting procedure of taking the decision of issuance of residence permit, cause a lot of problems of challenges. In some cases, people are forced to wait the decision until the last day of the validation of their visa, while others leave the country for a while and wait for the decision separately from their families not in Lithuania.

Unfavourable conditions for family migrants to arrive and to stay permanently in Lithuania might be the reasons why some persons do not think about their social adaptation into the society (do not study Lithuanian language, do not try to incorporate into local community, etc.). Facing challenges receiving residence permit and later trying to extend it, they feel insecure and uncertain about their and their families' future in the country.

The results of the study show that it would be important for policy makers to reconsider some requirements for family reunification in Lithuania. For instance, to shorten obligation of two years period of residence in the country to reunify with the family and to be more flexible regarding to the amount of sufficient means of subsistence. As well as, it is important to make the decision process of issuance/ extension of residence permit more rapid and more efficient. Such conditions would facilitate migrants' social adaptation and would also create more opportunities for their prospects of long-term residence in Lithuania.

\section{References}

1. Berry, J.W. (1997). Immigration, acculturation, and adaptation. Applied psychology: an international review, 46(1), 5-68.

2. Castles, St., Miller, M.J. (2009). The age of migration. International population movements in the modern world. Fourth edition. New York: Palgrave Macmillan.

3. Eurostat (2017). Residence permits statistics, October 2017.

[online] [accessed 30 June 2018]. Available from Internet: <http://ec.europa.eu/eurostat/statisticsexplained/index.php/Residence_permits_statistics>.

4. Huddleston, T., Bilgili, Ö., Joki, A.L., Vankova, Z. (2015). Migrant integration Policy index 2015. Barcelona/ Brussels: CIDOB and MPG.

5. Huddleston, T., Tjaden, J.D. (2012). Immigrant citizens' survey. How immigrants experience integration in 15 European cities. Brussels: King Baudouin Foundation and the Migration Policy Group.

6. Huijnk, W., Verkuyten, M., Coenders, M. (2012). Family life and acculturation attitudes: a study among four immigrant groups in the Netherlands. Journal of Ethnic and Migration Studies, Vol. 38, No. 4, 555-575.

7. Kasatkina, N., Leončikas, T. (2003). Lietuvos etniniu grupiu adaptacija: kontekstas ir eiga. Vilnius: Eugrimas.

8. Migrant Integration Policy Index (MIPEX 2015), [online] [accessed 30 June 2018]. Available from Internet: <http://www.mipex.eu/>.

9. Migration department under the Ministry of the Interior. "Migration Yearbooks", Vilnius, 2015, 2016, 2017 [online] [accessed 30 June 2018]. Available from Internet: <www.migracija.lt/index.php?683399458>.

10. Pascou, Y. Labayle, H. (2011). Conditions for family reunification under strain. A comparative study in nine EU member states. King Baudouin Foundation, European Policy Centre, Odysseus Network.

11. Portes, A., Rivas, A. (2011). The adaptation of migrant children. The Future of Children, Vol. 21/ No. 1/ Spring 2011, 219-246. 
12. Portes, A., Rumbaut, R.G., Berkeley, A. (2001). Legacies: the story of the immigrant second generation. University of California Press, New York: Russell Sage Foundation.

13. Portes, A., Zhou, M. (1993). The New Second Generation: Segmented Assimilation and Its Variants. The Annals of the American Academy of Political and Social Science. Vol. 530, Interminority Affairs in the U. S.: Pluralism at the Crossroads (Nov., 1993), pp. 74-96.

14. Republic of Lithuania Law on the Legal Status of Aliens. Official Gazette. 2004, No IX-2206. 